\title{
Employability Skills of Tourism Vocational High School Student through Collaborative Inquiry Learning Model
}

\author{
K. Primanti \\ Sekolah Pasca Sarjana Universitas Pendidikan Indonesia \\ Program Studi Pendidikan Teknologi dan Kejuruan \\ Bandung, Indonesia \\ krisna.primanti@hotmail.com
}

\begin{abstract}
The research aims to know the improvement of employability skills of Tourism Vocational High School students through collaborative inquiry learning model implementation. The employable skills of vocational high school students are observed from problem solving skill aspect, collaborative skill and communicative skill that must be mastered by vocational high school students to be skilled workers. Syntax in collaborative inquiry learning model consists of framing the problems, collecting the evidence, analyzing evidence, documenting, sharing and celebrating. The research used quasi experimental design "Single - Group Interrupted Time - Series Design". The technic uses : 1) Subjective test to measure students' problem solving skill; 2) Observation sheet to observe the syntax implementation of collaborative inquiry learning model and to measure students' collaborative and communicative skills; 3) Questionnaire to know students' perceptions of collaborative inquiry learning model implementation towards student's employability skills improvement. Population used in this research were Teacher and Student of Tourism Vocational High School. Students of Tourism Vocational High School as many as 43 people and teachers as an observer for 5 people in Yapari Aktripa Vocational High School Bandung as a sample. The result shows that through collaborative inquiry learning model, students' employability skills such as problem solving skill, collaborative skill, and communicative skills are improved in every treatments, and students' perception of collaborative inquiry learning model gets positive responses.
\end{abstract}

Keywords-employability skills, tourism vocational high school students, collaborative inquiry

\section{INTRODUCTION}

Industrialists look for prospective employees who have qualifications and work experience that was formed from the technical skills, employability skills, and personal attributes [1]. Employability skills are also well-known in other terms, such as soft skills, competencies skills, common skills, generic skills, essential skills, key skills, basic skills, necessary skills and transferable skills [2]. Employability skill is a term that integrate someone' skills to be able to work in work environment. Employability skills are important to be mastered by those who are going to enter work place, one of them is vocational students are lead to be able to fulfill industrial's need in laboring. It becomes very clear, educational institutions like vocational schools have to form the graduates to be able to work in industrial and work hard to fulfill what industrialist need.

The problems occur, in vocational implementation which has purposes to form graduates as quality human resources, are important to be solved. The problems are: (1) Learning process is still teacher-centered, therefore vocational students are tend to be passive and the materials are not contextual learning with their work environment; (2) Problem solving skills are low, they cannot solve the problem well individually or in group; (3) Collaborative skills are not maximum, theories or practical. They need more time to accomplish the task in group; (4) communicative skills need to be improved. It can be seen when students present their presentation, about their discussion or practical results. They are not able to arrange what they have to say well yet and to report systematically, clearly, and informatively; (5) learning methods in vocational are not varied, it can be seen that most of teachers use the same methods, whereas, the demand and characteristic each basic competencies in group $\mathrm{C}$ (vocational) are different. They make the mastery of competencies are not achieved thoroughly; (6) the right learning methods are required to optimize students' participation actively and to improve employability skills of vocational students to achieve success in working place.

Strategic ways to solve the problems in vocational school implementation are focus on academic learning process and vocational training through selecting the learning models that able to improve employability skill as industry demand. "The characteristics of future work field require a high level thinking, problem solving and collaborative working skills [3]. It is in accordance with the result of Economiest Intelligence Unit (EIU) survey about three main skills that needed by industrialists in industry, namely (1) Problem solving, (2) Team work dan (3) Communication. [4]. 
Therefore, aspects of enhanced employability skills in this study include problem-solving skill, collaborative skill and communicative skill.

\section{THEORETICAL BASIS}

Based on former study, problem solving skills, collaborative skills, and communicative skills can be trained through guided inquiry learning model and constructive collaborative learning model. Collaborative guided inquiry learning model can improve achievement than noncollaborative guided inquiry learning model [5]. Similar study that focus on students' soft skill also shows similar result, namely students' soft skill involved communicative skill, thinking skill, problem solving skill, and work in team improve in every meeting, students' mastery learning (psychomotor and cognitive) exceed the mastery maximum limit and students' response to soft skill improvement after applying guided inquiry learning model is positive [6]. It is the preliminary finding to be a reference that employability skill as students' achievement manifestation can be improved through learning model implementation that combine inquiry collaborative model namely collaborative inquiry learning model.

Collaborative inquiry is a learning model that combine inquiry approach and work in team so that are able to lead students into scientific athmosphere in learning activity through observation or direct experiment to produce new knowledge in groups. Students are going to be involved actively in finding new knowledge through scientific approach. Collaborative inquiry learning model syntax that is implemented in this study consists of framing the problems, collecting the evidence, analyzing evidence, and documenting, sharing, and celebrating [7].

Implementation of the learning model of collaborative inquiry was conducted at study Nutrition Sciences because based on observation and analysis of the learning is done by lectures, students assigned to record the content of the material be explained by teachers, students get the opportunity to ask if there are materials that are not well understood and studied the records independently. Completion of learning materials depending on the speed level of understanding of each student, but the student activity yet seen its full potential in the learning process in the classroom. This leads to students' understanding of different so while following the practicum students still confused and do not know what to do.

Vocational students have difficulty understanding the material content of Nutrition Sciences as knowledge is essentially weak, in line with the results of a study that found that the level of mastery of knowledge of food and nutrition owned by high school students in Bandung district shows more than half $(70.29 \%)$ are in criteria rather low, a small portion of each $(16.67 \%)$ level of mastery of food and nutrition is low and (13:04\%) is at a sufficient criteria [8]. The data shows that the level of mastery of the knowledge of Nutritional Sciences at the adolescent level of SMU / SMK is still not good, so the learning lab Nutrition Sciences vocational students are also not maximized.
Student learning activities are still limited to the physical activities under the instruction of teachers, have not seen any understanding of the concept of the material and mastery of skills in their entirety by the students after the practicum. Students also do not get a picture of the real benefits of the learning outcomes of Nutrition Sciences at the workplace because of the current learning material is still theoretical Nutrition transferred and accepted students as knowledge alone. In addition, students can not apply the material to situations or other problems, are not able to manage the work in groups so that a long time tend to be practical as well as during the given question, the students have not been able to deliver answers to the systematic, clear and informative. At the end of the lesson the teacher gives a test for each individual practice, the results are still not up to the student to understand and carry out the practice independently.

The aims of collaborative inquiry learning model implementation are to (1) describe the implementation of collaborative inquiry model syntax in Nutrition learning, theory and practical; (2) find the data of SMK Pariwisata students' employability skill improvement after following Nutrition learning with collaborative inquiry model, and (3) describe students' perception about collaborative inquiry model implementation toward the students' of SMK Pariwisata employability skills improvement. In collaborative inquiry learning, each member carries out his/her task according to his/her experience and capability. Thus, students will be accustomed to responsible and become their habit in work place. Teachers' roles in collaborative inquiry is not just giving explanation in front of class, but have roles as facilitator, model, and guide, give feedback, and guidance on students' learning effort.

\section{METHODS}

This research using quasi-experimental design with "Single - Group Interrupted Time - Series Design" where the treatment was done three meetings with different material difficulties. The research design can be showed by table 1:

\section{TABLE I. Table RESEARCH DESIGN}

Single-Group Interrupted Time - Series Design

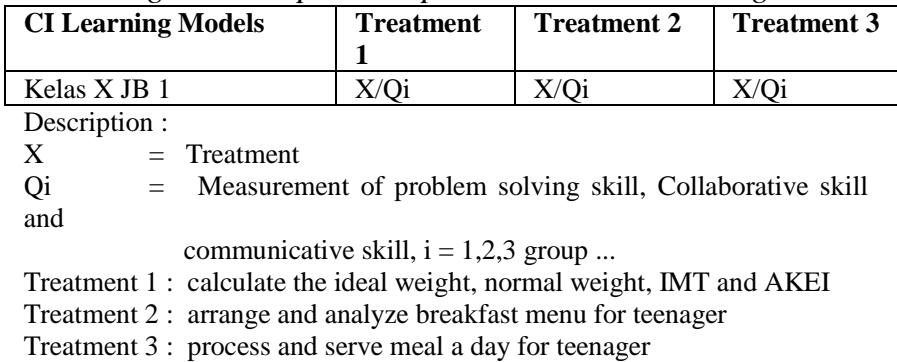

The population in this research was the students and teachers of SMK is Tourism with samples are 43 students of class X Kompetensi Keahlian Jasa Boga and 5 teachers of vocational subjects as observer. Collect the data using: 1) subjective test to measure students' problem solving skill; 2) observation sheet to measure the implementation of collaborative inquiry learning model syntax and to measure 
students' collaborative and communicative skills; 3) questionnaire to know students' perception about collaborative inquiry learning model implementation towards students' employability skill improvement.

The research instruments as learning equipments are validated by expert judgement namely 2 lecturers, nutrition science learning expert in PKK program study Pendidikan Tata Boga FPTK UPI and 2 teachers, nutrition science learning expert in SMKN 9 Bandung and SMKN 2 Baleendah. Treatment Implementation of learning activities by collecting the data as the result of observation learning model syntax implementation, collaborative and communicative skills, measuring problem solving skill test and questionnaire. The data analysis obtained through observation, they contain 'yes' and 'no' answers processed and analyzed using percentages of agreements (PoA) formula between observer [9].

\section{Persentages of agreements $=-$ Agreements $x$ $100 \%$ \\ (Disagreements + Agreements $)$}

Data from the questionnaires were processed using frequency percentage formula [10]. The interpretation of the data in this research using restriction [10]. The data has been analyzed subsequently interpreted based on the limitation [11]. The data of problem solving skill test become priceless finding as quality learning measurement to measure problem solving skills and assess mastery learning students use assessment guidelines and the conversion value as below :

TABLE II. CONVERSION VALUE

\begin{tabular}{|l|l|l|l|}
\hline No & Nilai & Huruf & Keterangan \\
\hline 1 & $\geq 88,26$ & A & Very Good \\
\hline 2 & $75.6-88.25$ & B & Good \\
\hline 3 & $62.76-75.5$ & C & Good Enough \\
\hline 4 & $50,01-62,75$ & D & Less \\
\hline 5 & $\leq 50$ & E & Very Less \\
\hline
\end{tabular}

\section{RESUlT AND DisCUSSION}

\section{A. Instrument Validation by Expert Judgment}

Results of the validation of research instruments by educational experts Paket Keahlian Jasa Boga lecturers and teachers stated that the learning instrument of Nutrition Sciences using models of collaborative inquiry for treatment 1 , treatment 2 and treatment 3 gain value - average 81 criteria very well as well as insrumen research get value average 86 criteria very well so that the whole instrument can be used without revisions presented in Table 3 and Table 4.
TABLE III. VALIDATION OF RESEARCH INSTRUMENT

\begin{tabular}{|c|c|c|c|}
\hline No & Asessed Component & $\begin{array}{r}\text { The average of } \\
\text { Value of meeting }\end{array}$ & Criteria \\
\hline 1 & $\begin{array}{l}\text { Implemented observation sheet syntax } \\
\text { Collaborative Inquiry Learning Models }\end{array}$ & 23 & \\
\hline 2 & Problem Solving Skill test & 23 & \\
\hline 3 & $\begin{array}{l}\text { Observation sheet collaborative skill and } \\
\text { Communicative skills student }\end{array}$ & 20 & \\
\hline 4 & $\begin{array}{l}\text { Student perception questionaire about } \\
\text { Improving employability skills of students } \\
\text { Through collaborative Inquiry learning models }\end{array}$ & 20 & \\
\hline & Total Scores & 86 & Very Good \\
\hline \multicolumn{2}{|c|}{ GENERALE VALIDATION } & \multicolumn{2}{|r|}{ very Goou } \\
\hline
\end{tabular}

Description :
$00-21=$ Not Good
A. = Can be used without revision
$22-43=$ Good Enough
$44-65=$ Good
B. = Can be used with a small revision
$66-88$
= Very Good
C. = Can be used with revision
D. = Can not be used

TABLE IV. VALIDATION OF LEARNING EQUIPMENTS

\begin{tabular}{|c|c|c|c|c|}
\hline No & Assesed component & $\begin{array}{r}\text { The } \\
\text { Value }\end{array}$ & $\begin{array}{l}\text { average } \\
\text { of meeting }\end{array}$ & Criteria \\
\hline 1 & $\begin{array}{l}\text { indocator and learning objectives } \\
\text { formulated based aspects of competence } \\
\text { (cognitive, affective, psychomotor) using } \\
\text { Operational words, describe the achievements } \\
\text { Relevant to the target }\end{array}$ & and & 81 & Very Good \\
\hline 2 & $\begin{array}{l}\text { Systematic teaching materials, proportionnate } \\
\text { Referring to appropriate learning objectives an } \\
\text { Achievement of competence }\end{array}$ & & 81 & Very Good \\
\hline 3 & $\begin{array}{l}\text { Approaches and methods adapted to the basic } \\
\text { Competence, relevant to the purpose and condi } \\
\text { Of learning and support the student's potentia }\end{array}$ & & 81 & Very Good \\
\hline 4 & $\begin{array}{l}\text { Scenarios are prepared for any purpose student } \\
\text {-Centered learning, learning models and descri } \\
\text { Application of a proportional allocationl }\end{array}$ & $\begin{array}{l}\text { t- } \\
\text { ibe the }\end{array}$ & 81 & Very Good \\
\hline 5 & $\begin{array}{l}\text { Tools, material, media and learning resources } \\
\text { Accordance with demands of basic competenci } \\
\text { Objectives and learning condition as well as su } \\
\text { The development of student potential }\end{array}$ & $\begin{array}{l}\text { in } \\
\text { ies } \\
\text { upport }\end{array}$ & 81 & Very Good \\
\hline & Outlines the types, form and evaluation tools & & 81 & Very Good \\
\hline \multicolumn{2}{|r|}{ GENERAL VALIDATION } & \multicolumn{3}{|c|}{$\mathbf{A}$} \\
\hline
\end{tabular}

Description :

$\begin{array}{lll}00-20 & =\text { Not Good } & \mathrm{A}=\text { Can be used without revision } \\ 21-41 & =\text { Good Enough } & \mathrm{B}=\text { can be used with a small revision } \\ 42-62 & =\text { Good } & \mathrm{C}=\text { can be used with revision } \\ 63-84 & =\text { Very Good } & \mathrm{D}=\text { can not be used }\end{array}$

$63-84=$ Very Good $\quad \mathrm{D}=$ can not be used

\section{1) Syntax of Collaborative Inquiry Learning Model} Implementation

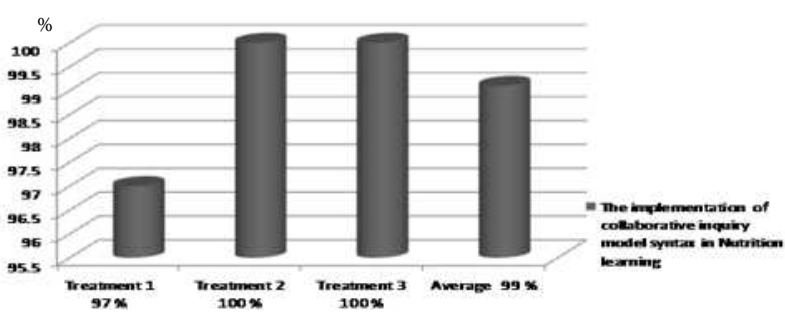

Fig. 1. The Percentage of Syntax of Collaborative Inquiry Learning Model Implementation in Nutrition Learning Treatment 1, Treatment 2 and Treatment 3

Based on figure 1, it can be found out that syntax of collaborative inquiry learning model Implemented very high in every treatment are treatment 1 calculate the ideal weight, normal weight, IMT and AKEI, treatment 2 arrange and analyze breakfast menu for teenager dan treatment 3 process and serve meal a day for teenager. 
Collaborative inquiry learning model that implemented in experiment class three times has figured out structured teacher and students' activities so that the learning athmosphere is realized $99 \%$ (very high), means that collaborative inquiry in this research can be said as main major in changing process and learning result that reached by students after the research because well prepared of learning materials along with validation result of expert judgment (tabel 3 dan 4).

\section{2) Employability Skills Improvement of Tourism} Vocational School Students

Vocational students have been able to understand the problem or task that is given to the learning of Nutrition by outlining what was asked, what is known and how to solve problems or tasks assigned. This is indicated by high scores on measures to formulate the problem, plan completion, collect evidence and carry out the settlement plan presented in Figure 2 below:

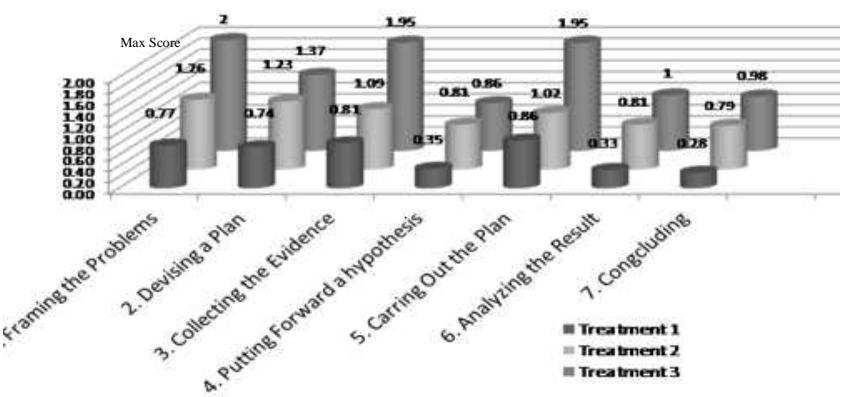

Fig. 2. The Percentage of Syntax of Collaborative Inquiry Learning Model Implementation in Nutrition Learning Treatment 1, Treatment 2 dan Treatment 3

Figure 2 shows low score at putting forward a hypothesis, analyzing the result and concluding, means that analyzing skill on vocational school students is still low, both analyze evidence to put forward hypothesis and analyze the result to conclude. Low ability to analyze the vocational students in learning Nutritional Sciences is due in vocational learning more use of direct learning. More teachers provide instruction primarily on practical class, it makes students are accustomed to receive instructions and materials of a teacher than to construct their own knowledge and make it as an independent experiment. However, with the design of learning models hone problem-solving skills to students is one problem solving approach in the implementation of collaborative inquiry learning model through exercises and practice solving problems, the ability to analyze the vocational students can be improved.

The findings of an improved skills to analyze the students in this study refute the findings of the study suggest that the skill of analysis, synthesis and evaluation of vocational students can not be upgraded because they do not master the material and basic knowledge is weak. Vocational students are not active and creative because of big class, their ability is heterogen [12]. With the design of group learning more proportionate terms as is done in a number of collaborative inquiry learning, the learning activities can be better managed so as to maximize the ability of students especially addressing the ability of vocational students are heterogeneous.

The result of problem solving measurement can be used to know students' mastery that can be seen in picture 3 . There is an improvement in percentage of problem solving test score in every treatment. At the end of treatment 3, 43 students in total, 5 students (12\%) get very good score, 13 students $(30 \%)$ get good score, 20 students $(47 \%)$ get enough score, 1 student (2\%) gets low score, while 4 students $(9 \%)$ get score less than 50 with very low score.

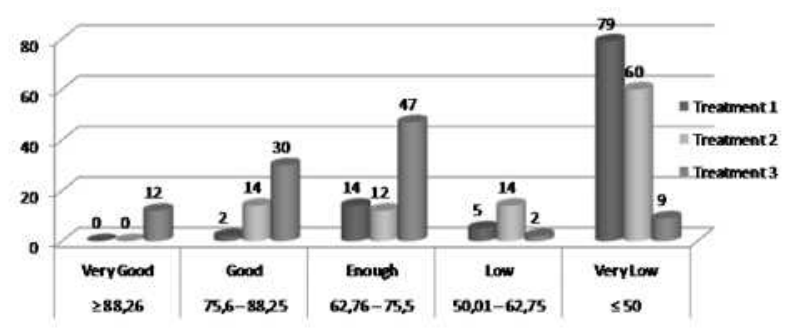

Fig. 3. Diagram Percentage of Problem Solving Skill Test Score at Treatment 1, Treatment 2 dan Treatment 3

In learning process, not all students are able to understand, solve the problem well and master the competencies task, but by collaborating harmoniously their ability in groups, the best result can be achieved. Teamwork ability can be taught at home, school, religion institution, scout, and other social institutions [11], along with the theory, this research aims to implement the teamwork practice in learning process at school through collaborative inquiry model in Nutrition subject. The result is students' collaborative skill improve in every tretment that showed on this figure :

\section{Group Average}

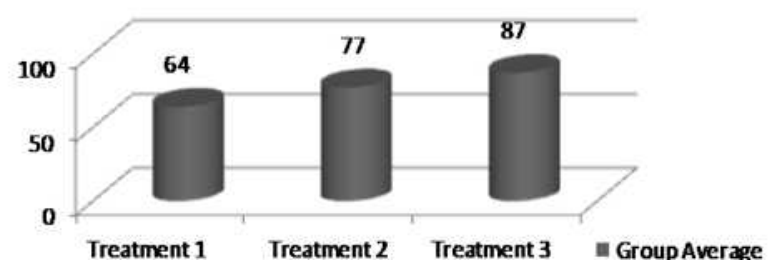

Fig. 4. The Average Percentage of Students' Collaborative Skill at Treatment 1, Treatment 2 dan Treatment 3

Base on picture 4, at the treatment 1 students' collaborative skill in completing the task of calculating ideal body weight, weight Normal, IMT and AKEI are at high criteria, this is because students are still unfamiliar with learning activities in a group that demands to help each other in achieving common goals and motivate other students to contribute actively, then the collaborative capabilities of students only reach $64 \%$.

Collaborative learning refers to teaching methods in which students with different backgrounds the ability, working together in small groups to achieve goals [14] as 
shown students in treatment 2, collaborative skill of students in compiling and analyzing a balanced menu for teenagers increased to $77 \%$ with high criteria, it shows that students are getting used to learning in groups and feel the benefits. In the third treatment skill of students in the collaborative process and present a balanced menu for teenagers increased again reach $87 \%$ with a very high criteria. It is proved that by implementing a model of collaborative inquiry learning Nutrition Sciences can enhance the collaborative capabilities of students to complete the task at each treatment so, is the right step when learning model is implemented on vocational learning other subjects.

Learning would be more meaningful and fun when students have a chance to ask question, find out the answer, collect data, discuss, and make summary so that they can find the answer of their questions. To implement this kind of learning process, it is important for students to have communicative skill to apply kind of suitable and effective communication in questioning, discussing, answering, and concluding a topic in learning. To practice the speaking skill, one has to be able to show his/her skill in choosing and using words or sentences so that the information, ideas, or what he/she is going to communicate are able to be accepted easily by the listener [12]. Along with the theory, during learning process, students' communication skills are trained though discussion, question and answer, and group presentation. The result is their communicative skills improve in ever treatment.

Figure 5 shows that the average percentage of the students communicative skills in group discussions, question and answer and presentation improves at every meeting, the first treatment more than a half of students have communicative skills in enough criterions. Based on observations of teachers observer students are not accustomed yet with learning process in group that needs them to communicate well in discussion or presentation, the Students still have difficulties in arranging words to deliver clearly and easily inderstood by others, especially some terms in English that need accurate pronounciation to avoid misunderstanding. Thus, the collaborative skills is only $52 \%$

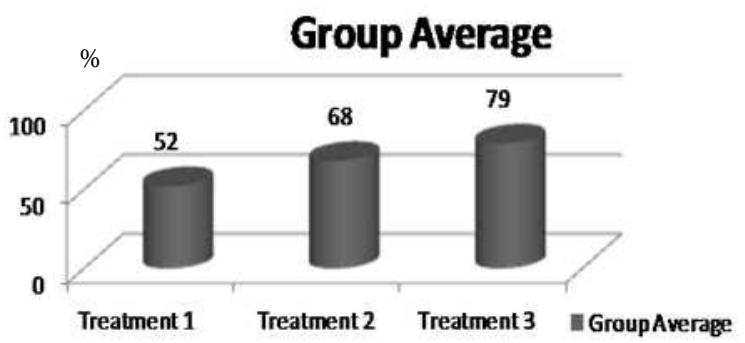

Fig. 5. Average Percentages of Students' Communicative Skills at Treatment 1, Treatment 2 dan Treatment 3

Figure 5 shows that at treatment 2 students' communicative skills improve into high criterion. It shows that students are accustomed with learning activity in group discussion, question and answer, and group presentation. Their confidence to speak in public increases to $68 \%$. At meeting 3, students' communicative skills also increase to $79 \%$ with high criterion. It is proved that by implementing a model of collaborative inquiry learning in Nutrition Sciences can improve the students communicative skill through oral communication exercises such as discussions, questions and answers and group presentations, so it is the right step when learning model is implemented on vocational learning other subjects.

3) Students' Perception about the Implementation of Collaborative Inquiry Learning Model toward Tourism Vocational School Students' Employability Skills Improvement

The data obtained in picture 6 shows that largery students (92\%) give positive perceptions. According to students grade X Kompetensi Keahlian Jasa Boga SMK Yapari Aktripa Bandung, learning process using collaborative inquiry model, where students divide into small groups and do some sequences experiments to solve the problem, is able to give different experience in learning. Students get better understanding about the usage of new knowledge for daily life in community and work place.

\section{Average Percentage of Student Perception}

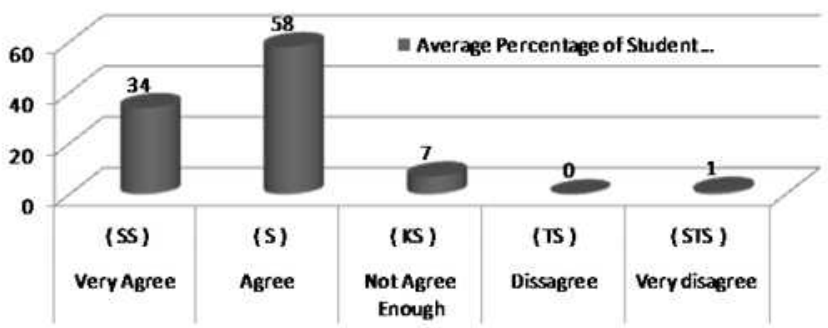

Fig. 6. Diagram Average Percentage Students' Perception about the Implementation of Collaborative Inquiry Learning Model toward Tourism Vocational School Students' Employability Skills Improvement

Students' response is highly positive because of the benefit they got during the Nutrition learning process using collaborative inquiry model, varied learning condition where they are able to optimize students' activities directly and actively, not only listen and receive knowledge from teachers. Students tend to show high enthusiasm in every activities that lead their body and mind, not only sit and listen, see and receive the learning materials. It can be seen from meeting 1 where learning material is theoretical, students show low enthusiasm. Especially when they are asked to retell the material in presentation, they find difficulties. Not like at meeting 2 and meeting 3, where students do the experiments in processing and serving ideal menu for teenager directly, students can explain their experiment result well and confidently.

Subjects in vocational lesson include some skill aspects, such as cognitive, affective, and psychomotor that have to be mastered by vocational school students to achieve integrate achievement by using employability skills. In late teenager group, not all of students are able to adjust learning method in vocational school because it is very different with junior high school. Learning demand in vocational school is high because, along with Vygotsky theory about ZPD, vocational students are demanded to master some sequences of task and 
competencies that are highly difficult individually but can be learnt and helped by adult (in this case teacher as facilitator) and other capable students.

Collaborative inquiry learning model will be accustomed students to learn more with other capable students. It proves that through collaborative inquiry learning, problem solving skill, collaborative skill, and communicative skill can be improved [16]. Therefore, collaborative inquiry learning model can be an alternative learning model that can be implemented in teaching-learning process in group $\mathrm{C}$ (vocational) that the demand of competency lead students into work readiness, employability skills..

\section{CONCLUSION}

(1) Syntax of collaborative inquiry model implementation in Nutrition subject is very high, it is influenced by well-prepared syllabus, the design of lesson preparation, learning materials, and evaluation as research instrument. (2) This high of syntax of collaborative inquiry model implementation can be said as important factor in Nutrition learning process and achievement improvement through framing the problems, collecting the evidence, anayzing evidence, documenting, sharing and celebrating steps. (3) Experiment class that impelements the collaborative inquiry model has improvement in problem solving skill, collaborative skill, and communicative skill. Thus, it can be said that collaborative inquiry learning model can improve emplorability skills of tourism vocational students. (4) students of grade X Kompetensi Keahlian Jasa Boga SMK Yapari Aktripa Bandung have high positive perception of collaborative inquiry model implementation, including problem solving skill, collaborative skill, and communicative.

This research still has limitations that allow it to be developed by further research, namely: (1) the syntax learning model of collaborative inquiry implementation in this research only observed in terms of quantity alone to generate data in the form of statements executed or not by the teacher models, has not been able to describe the quality of its appropriateness, thus allowing for further research to develop research that can describe the quality of the syntax feasibility study model qualitatively; (2) The improves in employability skills that are discussed in this research are still partial, namely of 8 components to build employability skills including Communications, Team Work, Problem Solving, Initiative and enterprise, Planning and Organizing, Self Management, Learning, and Technology, only 3 components discussed the improvement is communication, team work and problem solving, making it possible for further research to develop research that can be discussed increasing employability skills of students includes 8 components; (3) To implement this collaborative inquiry learning model, observers are needed to be able to observe students' activities in learning process to measure collaborative skill and communicative skill and this learning model can be done by at least two teachers (team teaching).

\section{REFERENCES}

[1] UKCES, The employability challenge, full report. [Online]. Tersedia : http://www.ukces.org.uk/pdf/808-UKCESEmployability/ChallengeFinal.pdf, (2009).

[2] Yassin, S., at. Al, Implementation of generic skills in curriculum. originally published in the proceedings of the EDU-COM 2008 international conference. sustainability in higher education: directions for Change, Edith Cowan University, Perth Western Australia (hlm. 570 - 582) This Conference Proceeding is posted at Research Online. http://ro.ecu.edu.au/ceducom/54 (2008).

[3] Ana, A., \& Nurlaela, L. Development model of patisserie projectbased learning. Journal of Technical Education and Training, 4 (2), (2013)

[4] Economiest Intelligence Unit (EIU). (2005). Slovenia : education New York. Views Wire, 18 May (2005a).

[5] Eprysca, dkk., Perbedaan hasil belajar kimia materi hidrolisis garam siswa SMK Negeri 1 Rejotangan Tulungagung yang dibelajarkan dengan model pembelajaran inkuiri terbimbing kolaboratif dan non kolaboratif. (Tesis). Universitas Negeri Malang, (2013).

[6] Ardiansyah, M.A., Melatih soft skills siswa melalui model pembelajaran guided inquiry pada proses pembelajaran praktikum merangkai power supply kelas X di SMK Negeri 3 Surabaya. Jurnal Pendidikan Teknik Elektro, 03(03), hlm. 613 - 621, (2014).

[7] Donohoo, J., Collaborative inquiry for educators : a facilitator's guide to school improvement. Library of congress cataloging-inpublication data : United States of America, (2013).

[8] Nikmawati, Ellis Endang dkk. Status gizi dan penguasaan pengetahuan pangan dan gizi siswi SMU di Kabupaten Bandung. Pusat Studi Peranan Wanita, Lembaga Penelitian UPI. (2004).

[9] Grinnell, Jr.M., Social Work Research and Evaluation. Third Edition. Illonis: F.E. Peacock Publisher, Inc., (1988)

[10] Ali, M., Penelitian pendidikan prosedur dan strategi. Jakarta : Balai Pustaka, (2007).

[11] Riduwan, Dasar - dasar statistika. Bandung : Alfabeta, 2012

[12] Pardjono dan Wardaya, Peningkatan kemampuan analisis, sintesis dan evaluasi melalui pembelajaran problem solving. Jurnal FT UNY. 28, (3), 1-13, (2009)

[13] Apriono, D., Meningkatkan keterampilan kerjasama siswa dalam belajar melalui pembelajaran kolaboratif. Prospektus Jurnal : IX (2), hlm. 159-172, (2011).

[14] Ana, Ana, and Neni Rohaeni. "Pengembangan tugas akhir melalui project based learning model untuk meningkatkan generic green skills siswa." JPTK 21.3 (2015).

[15] Dimyati \& Mudjiono, Belajar dan pembelajaran. Jakarta : Rineka Cipta, (2002).

[16] [16] Bella, T. at.al., Collaborative inquiry learning: models, tools, and

[17] challenges. [Online], DOI:10.1080/09500690802582241, (2010) 